\title{
Keterampilan Berpikir Kritis Calon Guru Kimia sebagai Kesiapan Menghadapi Revolusi Industri 4.0
}

\author{
Oktariani $^{1}$, Asyti Febliza ${ }^{2}$, Nurul Fauziah ${ }^{3}$ \\ ${ }^{1,2}$ Program Studi Pendidikan Kimia, Universitas Islam Rian \\ ${ }^{3}$ Program Studi Pendidikan Biologi, Universitas Islam Riau \\ e-mail: \\ 1 oktariani@edu.uir.ac.id \\ 2 asytifebliza@edu.uir.a.id \\ 3 nurulfauziah@edu.uir.ac.id
}

\begin{abstract}
.
This research was conducted to identify and describe prospective teachers' critical thinking skills profile as readiness to face the industrial revolution 4.0. This research was a descriptive research. Research subjects were chemistry education students who are prospective chemistry teachers. The instruments used in this study were the Critical Thinking Ability Test and Critical Thinking Ability Questionnaire. The instrument used is valid and reliable. The results of the study showed that the critical thinking skills of prospective chemistry teacher students are still in sufficient criteria with average score 46,7. It was also found that students' critical thinking skills in $5^{\text {th }}$ semester were better than those in semester $3^{\text {rd }}$ and $1^{\text {st }}$ with average score 57,46 and 41. This result was also supported by differences in student performance for each indicator of critical thinking skills. Chemistry students show better performance on indicators of building basic skills compared to other critical thinking skills indicators. Meanwhile, the indicators on building strategies and tactics of chemistry education students still showed poor performance than other indicators. This needs to be improved immediately in order to prepare prospective chemistry teachers who are ready to compete in facing the industrial revolition 4.0. Improvements can be made by designing learning methods, teaching materials and evaluation tools that can improve students' critical thinking skills.
\end{abstract}

Keywords: critical thinking skill, education 4.0., prospective chemistry teachers, revolutioanl industry 4.0

\begin{abstract}
ABSTRAK.
Penelitian ini dilakukan untuk mengidentifikasi dan mendeskripsikan profil keterampilan berpikir kritis calon guru kimia sebagai kesiapan dalam menghadapi revolusi industri 4.0. Penelitian ini merupakan penelitian deskriptif. Subjek penelitian merupakan mahasiswa pendidikan kimia yang merupakan calon guru kimia. Instrumen yang digunakan dalam penelitian ini adalah tes keterampilan berpikir kritis dan kuisioner keterampilan berpikir kritis. Instrumen yang digunakan sudah valid dan reliabel. Hasil penelitian menunjukkan bahwa keterampilan berpikir kritis calon guru kimia masih berada pada kriteria cukup yaitu dengan skor rata-rata 46,7. Selain itu juga ditemukan bahwa keterampilan berpikir kritis mahasiswa semester 5 lebih baik dibandingkan semester 3 dan semester 1 dengan skor rata-rata masing-masingnya yaitu 57, 46 dan 41 . Hasil ini juga didukung dengan adanya perbedaan performa mahasiswa untuk masing-masing indikator keterampilan berpikir kritis. Calon guru kimia menunjukkan performa yang lebih baik pada indikator membangun keterampilan dasar dibandingkan dengan indikator keterampilan berpikir kritis lainnya. Sementara itu, pada indikator membangun strategi dan taktik calon guru kimia masih menunjukkan performa yang kurang baik dibandingkan dengan indikator yang lainnya. Hal ini perlu segera diperbaiki guna mempersiapkan calon guru kimia yang siap bersaing menghadapi era revolusi industri 4.0. Perbaikan dapat dilakukan dengan cara merancang metode pembelajaran, bahan ajar dan alat evaluasi yang dapat mengasah keterampilan berpikir kritis peserta didik.
\end{abstract}

Kata kunci: calon guru kimia, keterampilan berpikir kritis, pendidikan 4.0, revolusi industri 4.0 


\section{PENDAHULUAN}

Saat ini kita sudah memasuki abad 21, dimana perkembangan industri di dunia berada pada masa revolusi industri ke-4 (4IR) atau yang lebih dikenal dengan istilah revolusi industri 4.0. Masa ini ditandai dengan kehadiran teknologi-teknologi baru yang memadukan dunia digital, fisik dan biologis yang diwujudkan dalam bentuk perangkat komputer, robot, kendaraan otonom, digitalisasi dan berbagai bentuk kecerdasan buatan, sehingga pada era ini manusia, peralatan, dan mesin dirancang untuk mampu berkomunikasi menggunakan teknologi internet (Maria et al., 2016). Perkembangan industri ini tentunya membawa berbagai tantangan baru diantaranya: ancaman terhadap kelestarian lingkungan akibat eksploitasi sumber daya alam, informasi yang berlebih (overload information), ketimpangan sosial ekonomi serta bertambahnya penganguran akibat ketidaksiapan Sumber Daya Manusia (SDM) baik dari segi pengetahuan maupun keterampilan.

Berdasarkan penelitian kompetensi tamatan sekolah menengah, diploma maupun perguruan tinggi saat ini dalam hal kompetensi berpikir kritis dan pemecahan masalah, berkomunikasi dan bersosialisasi, serta pemanfaatan teknologi masih kurang (Trilling \& Fadel, 2009). Padahal kompetensi ini merupakan kompetensi utama yang menjadi bekal bagi siswa untuk bertahan hidup di abad 21 atau yang kita kenal dengan istilah revolusi industri 4.0. Kompetensi yang harus dimiliki siswa jika ingin bertahan hidup revolusi industri 4.0 ini diantaranya: keterampilan berpikir kritis (critical thinking skills), kemampuan memecahkan masalah (problem solving skills), kolaboratif dan kepemimpinan (collaboration and leadership), kemampuan beradaptasi, jiwa enterpreneurship, kemampuan berkomunikasi, kemampuan mengakses dan menganalisis informasi serta rasa ingin tahu dan imajinasi yang tinggi (Wagner, 2017). Hal ini sejalan dengan temuan yang dikemukakan oleh US-based partnership for 21st Century skills ((P21)., 2018)yang mengindentifikasi bahwa kompetensi yang dibutuhkan pada era ini adalah "The 4Cs" yaitu Communication, Collaboration, Critical Thinking and Creativity.

Perubahan zaman ini tentunya harus diiringi oleh perubahan dunia pendidikan. Sebab pendidikan merupakan solusi utama untuk mempersiapkan generasi yang siap untuk berkompetensi revolusi industri 4.0. Perubahan dalam pendidikan juga diperlukan agar proses pendidikan selaras dengan keadaan dan kebutuhan peserta didik di era industri 4.0. Pendidikan 4.0 merupakan merupakan pendidikan yang berupaya untuk mengembangkan kompetensi abad 21 yang terdiri dari 3 komponen besar yaitu: kompetensi berpikir, berbuat dan bertahan hidup (Greenstein, 2012). Oleh sebab itu, praktik pendidikan yang awalnya hanya berupa transfer ilmu pegetahuan dari guru ke siswa sudah tidak efektif lagi digunakan untuk mempersiapkan generasi muda yang akan berkompetensi di revolusi industri 4.0 (Firman, 2018). Lebih lanjut, ia menyatakan bahwa karakteristik pendidikan 4.0 mengarah pada beberapa kriteria pembelajaran yaitu: Pembelajaran student centered akan memberikan kesempatan pada peserta didik untuk mengembangkan minat dan bakatnya; Pembelajaran mengembangkan kemampuan peserta didik untuk menghimpun informasi dari segala sumber sehingga terjadi proses long-life learning; Pemanfaatan Information and Communication Technology (ICT) dan berbagai perangkat virtual memberikan fleksibilitas bagi peserta didik untuk menemukan sumber-sumber belajar yang berkualitas; Menekankan pembelajaran hands-on; Mengembangkan softskill berpikir kritis, kreatif, dan pemecahan masalah; Kolaborasi dan berinteraksi sosial; Memberikan fleksibilitas dalam proses pembelajaran (blended learning).

Berdasarkan penjelasan di atas terlihat bahwa keterampilan berpikir kritis merupakan salah satu keterampilan yang diperlukan dan perlu terus dibina agar peserta didik mampu bertahan hidup di revolusi industri 4.0. Berpikir kritis merupakan bagian dari High Order Thinking Skills (HOTS) atau kompleks. Berpikir kritis adalah kumpulan konsep-konsep yang dihubungkan dengan keterampilan dan strategi berpikir yang bermanfaat dalam membuat keputusan yang masuk akal sehingga dapat dipercaya (Rudinov \& Barry, 2004). Definisi yang berbeda diberikan oleh (Facione, 2011) yang menyatakan berpikir kritis merupakan pikiran yang mempunyai tujuan membuktikan maksud/pendapat, menginterpretasi sesuatu yang bermakna, dan menyelesaikan 
masalah. Menurutnya, inti berpikir kritis adalah deskripsi yang rinci dari sejumlah karakteristik yang saling berhubungan, meliputi interpretasi, analisis, evaluasi, inferensi, eksplanasi, dan pengaturan diri.

Keterampilan berpikir kritis yang dikembangkan pada penelitian ini berpikir kritis menurut Ennis, ada 12 indikator keterampilan berpikir kritis yang dikelompokkan dalam lima aspek keterampilan berpikir kritis, yaitu: (1) Memberikan penjelasan sederhana (Elementary clarification), indikator yang diukur yaitu memfokuskan pertanyaan, dengan sub indikator mengidentifikasi pertanyaan secara benar dan merumuskan pertanyaan yang bisa dijawab secara eksperimen; dan menganalisis argumen, dengan sub indikator mengidentifikasi kerelevanan melalui identifikasi informasi secara teoretik; (2) Membangun keterampilan dasar (Basic support), indikator yang diukur yaitu mempertimbangkan kredibilitas suatu sumber, dengan sub indikator mampu memberikan alasan berdasarkan pengetahuan yang dimiliki; (3) Kesimpulan, indikator yang diukur yaitu membuat deduksi dan mempertimbangkan hasil deduksi, dengan sub indikator mendeduksi secara logis; membuat induksi dan mempertimbangkan induksi, dengan sub indikator membuat generalisasi yang dapat menjawab rumusan pertanyaan; membuat dan mempertimbangkan nilai keputusan, dengan sub indikator penerapan prinsip/konsep yang dapat diterima dan mempertimbangkan dan menentukan nilai keputusan; (4) Membuat penjelasan lebih lanjut, indikator yang diukur yaitu mendefinisikan istilah, dengan sub indikator menyatakan pendapat dengan meyakinkan; (5) Strategi dan taktik, indikator yang diukur yaitu memutuskan suatu tindakan, dengan sub indikator memutuskan hal-hal yang akan dilakukan secara tentative melalui identifikasi informasi secara teknik dan memberikan alternatif lain untuk melakukan percobaan (Saputri et al., 2017; Supriyati et al., 2018).

Beberapa hasil penelitian sebelumnya menunjukkan bahwa sebagian besar tingkat keterampilan berpikir kritis peserta didik di Indonesia masih berada pada level rendah (Miftianah \& Nofia Nur., 2017; Agustin, et al., 2017). Menurut (Saputri et al., 2017) identifikasi tingkat keterampilan berpikir kritis peserta didik ini perlu dilakukan, sebab jika tingkat keterampilan ini sudah teridentifikasi maka guru maupun pengambil kebijakan dapat mencarikan solusi dan alternatif untuk menyiapkan berbagai cara untuk mengasah dan meningkatkan keterampilan berpikir kritis peserta didik. Sejauh ini belum ada penelitian terkait analisis keterampilan berpikir kritis calon guru kimia yang berorientasi revolusi industri 4.0. Oleh karena itu, penulis melakukan penelitian yang bertujuan untuk mengidentifikasi tingkat keterampilan berpikir kritis calon guru kimia. Melalui penelitian ini penulis ingin mendapatkan gambaran dan deskripsi tentang sejauh mana tingkat keterampilan berpikir kritis calon guru kimia sebagai bentuk kesiapan menghadapi revolusi industri 4.0, sehingga selanjutnya dapat merancang dan mengembangkan model pembelajaran yang dapat membantu peserta didik dan calon guru kimia mengembangkan kemampuan berpikir kritisnya.

\section{METODOLOGI}

Sesuai dengan permasalahan yang diteliti, maka jenis penelitian ini adalah penelitian deskriptif. Penelitian deskriptif bertujuan untuk menggambarkan dan menginterpretasikan suatu gejala, peristiwa atau kejadian dengan apa adanya tanpa memberikan perlakuan dan manipulasi variabel (Arikunto, 2006). Secara khusus (Harry, 2013) menjelaskan bahwa penelitian deskriptif ini bertujuan untuk memecahkan masalah aktual yang dihadapi serta bertujuan untuk mengumpulkan data/informasi untuk disusun, dijelaskan dan dianalisis. Penelitian ini bertujuan untuk mendeskripsikan dan memberikan gambaran terperici mengenai keterampilan berpikir kritis calon guru kimia sebagai upaya untuk persiapan menghadapi era revolusi industri 4.0.

Subjek penelitian ini adalah calon guru kimia berjumlah 30 orang. Data dikumpulkan melalui tes, kuisioner dan wawancara. Tes merupakan pengumpulan data dengan cara memberikan beberapa pertanyaan yang digunakan untuk mengukur pengetahuan dan keterampilan yang dimiliki 
individu atau kelompok (Arikunto, 2012). Tes yang digunakan dalam penelitian ini adalah tes keterampilan berpikir kritis untuk mengetahui dan mengukur keterampilan berpikir kritis dari subjek penelitian. Tes ini berupa tes essay yang dibuat berdasarkan aspek keterampilan berpikir kritis menurut Ennis yang terdiri dari memberikan penjelasan sederhana (elementary clarification), membangun keterampilan dasar (basic support), membuat kesimpulan, membuat penjelasan lebih lanjut dan menentukan strategi dan taktik (Saputri et al., 2017; Supriyati et.al., 2018).

Kuisioner pada penelitian ini digunakan untuk memperoleh informasi tambahan dari subjek penelitian berdasarkan hasil tes keterampilan berpikir kritis sekaligus untuk mengklarifikasi. Kuisioner dibuat menggunakan skala likert 1-4. Melalui kuisoner peneliti ingin menggali informasi langsung dari siswa tentang aktivitas dan keterampilan berpikir kritis mereka selama proses pembelajaran. Sementara itu, wawancara dilakukan untuk mengklarifikasi dan menggali informasi lebih lanjut dari mahasiswa berdasarkan hasil tes dan kuisioner. Wawancara dilakukan secara semi tersturuktur terhadap beberapa perwakilan mahasiswa.

Sebelum digunakan untuk mengumpulkan data, instrumen penelitian divalidasi dengan melakukan uji reliabilitas dan validitas Hasil validasi menunjukkan bahwa instrumen tes yang terdiri dari soal essay dapat digunakan karena sudah valid dengan nilai CVI sebesar 0,85 dan memiliki tingkat reliabilitas yang tinggi dengan nilai cronbach's alpa sebesar 0,8 sama halnya dengan instrument tes, instrumen kuisioner juga dapat digunakan karena sudah valid dan memiliki reliabilitas yang tinggi yaitu dengan nilai CVI sebesar 0,91 dan cronbach's alpa sebesar 0,82.

Prosedur penelitian ini dilakukan melalui tiga tahap, yaitu: tahap persiapan, tahap pelaksanaan, dan tahap penarikan kesimpulan. Tahap persiapan diawali dengan pembuatan dan validasi instrumen penelitian berupa tes keterampilan berpikir kritis, dan kuisioner keterampilan berpikir kritis. Instrumen tes dan kuisioner divalidasi ahli. Hasil validasi ini selanjutnya digunakan sebagai pemyempurnaan dan revisi instrumen sehingga instrumen siap untuk digunakan. Tahap pelaksanaan adalah tahapan dimana pengumpulan data dilakukan dengan melakukan tes keterampilan berpikir kritis. Setelah kedua langkah ini dilaksanakan selanjutnya mahasiswa diberikan kuisioner untuk mengklarifikasi langsung jawaban siswa serta untuk menggali informasi tambahan, sehingga terjadi proses triangulasi data dan data siap untuk dianalisis. Tahap penarikan kesimpulan merupakan tahap akhir penelitian ini. Data hasil penelitian yang sudah dianalisis kemudian dikaji berdasarkan teori-teori serta penelitian yang dilakukan sebelumnya, sehingga memperoleh kesimpulan. Sementara itu, pengelompokkan kriteria kemampuan berpikir kritis dibuat berdasarkan penelitian sebelumnya yang terkait dengan analisis keterampilan berpikir kritis.

\section{TEMUAN DAN PEMBAHASAN}

\section{Hasil Pencapaian Keterampilan Berpikir Kritis Berdasarkan Tes}

Hasil pengolahan dan analisis data hasil tes keterampilan berpikir kritis yang dilakukan terhadap 30 orang mahasiswa didapatkan tabel berikut ini:

Tabel 1. Distribusi frekuensi hasil tes keterampilan berpikir kritis mahasiswa

\begin{tabular}{cccc}
\hline No. & Rentang Perolehan Skor & Frekuensi & Kriteria \\
\hline 1 & $0-19$ & 2 & Sangat rendah \\
\hline 2 & $20-39$ & 8 & Rendah \\
\hline 3 & $40-59$ & 14 & Cukup \\
\hline 4 & $60-79$ & 6 & Tinggi \\
\hline 5 & $80-100$ & 0 & Sangat tinggi \\
\hline & Rata-rata & $\mathbf{4 6 , 7}$ & Cukup \\
\hline
\end{tabular}

Sesuai dengan tabel 1 di atas dapat disimpulkan bahwa berdasarkan skor rata-rata tes, mahasiswa calon guru kimia memiliki tingkat kemampuan berpikir kritis yang cukup dengan ratarata skor 46,7 . 
Berdasarkan tes, dari 30 orang mahasiswa ditemukan 2 orang mahasiswa yang memiliki skor pada kriteria keterampilan berpikir kritis sangat rendah. Mahasiswa yang berada pada kriteria rendah berjumlah 8 orang. Mahasiswa yang memiliki keterampilan berpikir kritis tinggi berjumlah 6 orang. Sementara itu, dari 30 orang mahasiswa, tidak satu orangpun yang berhasil meraih skor diatas 80 artinya tidak ada mahasiswa yang memiliki keterampilan berpikir kritis pada kriteria sangat tinggi. Nilai tertinggi dari tes keterampilam berpikir kritis ini adalah sebesar 74 yang diraih oleh mahasiswa pendidikan kimia semester 3 dan nilai terendah dari tes ini adalah 10 yang diraih oleh mahasiswa pendidikan kimia semester 3. Hasil rata-rata dari tes keterampilan berpikir kritis selanjutnya dianalisis lebih lanjut berdasarkan tingkatan semester perkuliahan. Berdasarkan hasil analisis skor tes masing-masing tingkatan semester didapatkan data sebagai berikut:

Tabel 2. Kriteria keterampilan berpikir kritis mahasiswa berdasarkan tingkatan/semester

\begin{tabular}{cccc}
\hline No & Tingkatan /Semester & Skor rata-rata & Kriteria \\
\hline 1 & 1 & 41 & Cukup \\
\hline 2 & 3 & 46 & Cukup \\
\hline 3 & 5 & 57 & Cukup \\
\hline
\end{tabular}

Berdasarkan tabel 2 di atas terlihat bahwa mahasiswa pendidikan kimia baik yang masih semester 1, 3 maupun 5 memiliki skor kemampuan berpikir kritis yang berada pada kriteria cukup. Meskipun terdapat beberapa orang yang memiliki skor tes pada kriteria tinggi dan rendah. Secara ringkas hasil pengelompokkan skor berdasarkan tingkatan semesternya dijabarkan dalam grafik berikut ini.

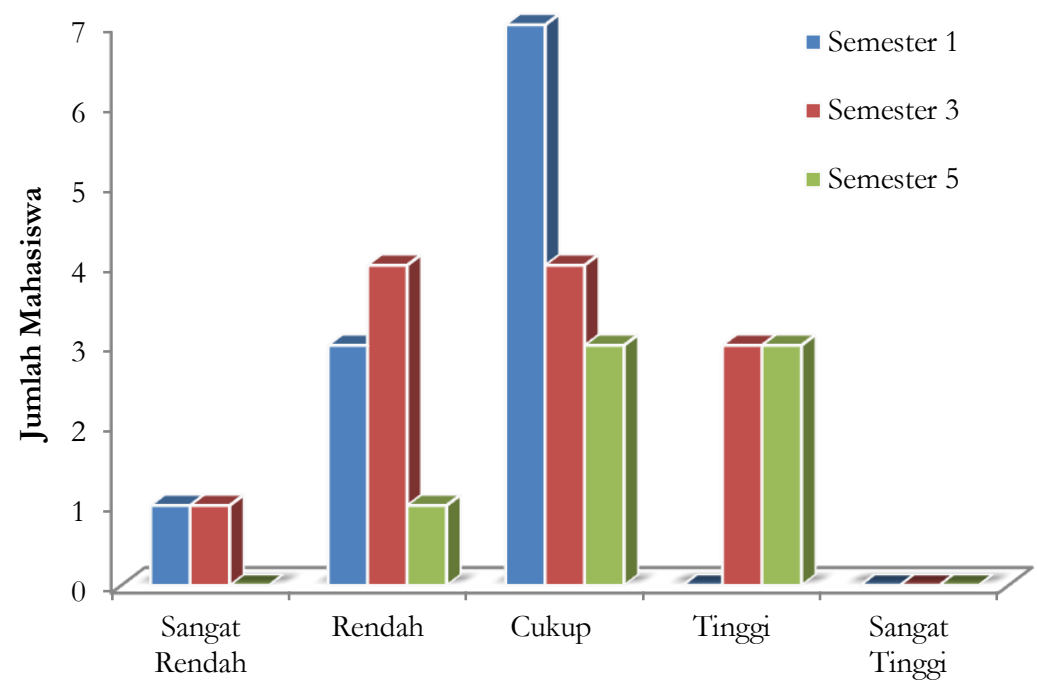

Kriteria Keterampilan Berpikir Kritis

Gambar 1. Grafik tingkat keterampilan berpikir kritis berdasarkan hasil tes

Berdasarkan grafik di atas, terlihat bahwa baik mahasiswa semester 1,3 maupun 5 tidak ada yang memiliki skor tes pada kriteria kemampuan berpikir kritis sangat tinggi yaitu dengan nilai diatas 80. Sementara itu jumlah mahasiswa semester 1 dan 3 yang berada pada kiteria sangat rendah sama-sama berjumlah 1 orang, sementara mahasiswa semester 5 tidak ada yang memiliki skor tes pada kriteria keterampilan berpikir kritis sangat rendah. Pada kriteria keterampilan berpikir kritis rendah jumlah mahasiswa semester 3 lebih banyak dbandingkan mahasiswa semester 1 dan 5 yaitu masing-masing berjumlah 4,3 dan 1 . 
Pada kriteria keterampilan berpikir kritis cukup, jumlah mahasiswa 1 yang berada pada kriteria ini lebih banyak dibandingkan mahasiswa semester 3 dan 5 yang masing-masing berjumlah 7,4 dan 3. Pada kriteria keterampilan berpikir kritis tingkat tinggi jumlah mahasiswa yang berhasil memperoleh skor pada kriteria ini baik mahasiswa semester 3 maupun 5 sama-sama berjumlah 3 orang. Sementara itu, mahasiswa semester 1 tidak ada satu orangpun yang memiliki skor tes pada kriteria tinggi. Data skor tes keterampilan berpikir kritis ini juga dianalisis per indikator keterampilan berpikir kritis. Hal ini dilakukan untuk memperoleh gambaran keterampilan berpikir kritis baik mahasiswa semester 1, 3 maupun 5 untuk setiap indikator kemampuan berpikir kritis. Berikut ini merupakan hasil analis skor tes per indikator.

Tabel 3. Hasil tes keterampilan berpikir kritis mahasiswa per indikator

\begin{tabular}{|c|c|c|c|c|c|c|}
\hline \multirow{2}{*}{ No } & \multirow{2}{*}{ Indikator Keterampilan Berpikir Kritis } & \multicolumn{4}{|c|}{$\begin{array}{l}\text { Rata-rata skor Per indikator } \\
\text { mahasiswa semester ke }\end{array}$} & \multirow{2}{*}{ Kriteria } \\
\hline & & 1 & 3 & 5 & $\begin{array}{l}\text { Rata- } \\
\text { rata }\end{array}$ & \\
\hline 1 & $\begin{array}{l}\text { Memberikan penjelasan } \\
\text { (memfokuskan pertanyaan, menganalisis argumen dan } \\
\text { memberikan penjelasan sederhana }\end{array}$ & 55 & 48 & 64 & 55,67 & Cukup \\
\hline 2 & $\begin{array}{l}\text { Membangun keterampilan dasar (mempertimbangkan } \\
\text { kredibilitas sumber dan kemampuan memberikan alasan) }\end{array}$ & 75 & 75 & 75 & 75 & Tinggi \\
\hline 3 & Membuat kesimpulan berdasarkan fakta & 23 & 40 & 54 & 39 & Rendah \\
\hline 4 & $\begin{array}{l}\text { Memberikan penjelasan lanjut (mendefinisikan istilah dan } \\
\text { mempertimbangkannya serta menyampaikan pendapat) }\end{array}$ & 34 & 43 & 44 & 40,3 & Cukup \\
\hline 5 & $\begin{array}{l}\text { Menyusun strategi dan taktik (memutuskan suatu } \\
\text { tindakan dan memberikan alternatif }\end{array}$ & 27 & 27 & 48 & 34 & Rendah \\
\hline
\end{tabular}

Tabel 3 di atas merupakan data hasil analisis skor tes per indikator keterampilan berpikir kritis. Berdasarkan data diatas terlihat bahwa pada indikator keterampilan berpikir kritis kedua yaitu membangun keterampilan dasar memiliki skor pada kriteria keterampilan berpikir kritis Tinggi. Pada indikator pertama dan ketiga yaitu memberikan penjelasan sederhana dan memberikan penjelasan lanjut mahasiswa berada pada kriteria Cukup. Sementara itu, untuk indikator kedua dan kelima yaitu membuat kesimpulan berdasarkan fakta dan menyusun strategi dan taktik berdasarkan skor rata-rata tes mahasiswa meraih skor pada kriteria Rendah. Secara singkat, rincian skor rata-rata tes keterampilan berpikir kritis per indikator keterampilan berpikir kritis untuk masing-masing tingkatan semester baik semester 1, 3 maupun 5 digambarkan pada grafik di bawah ini.

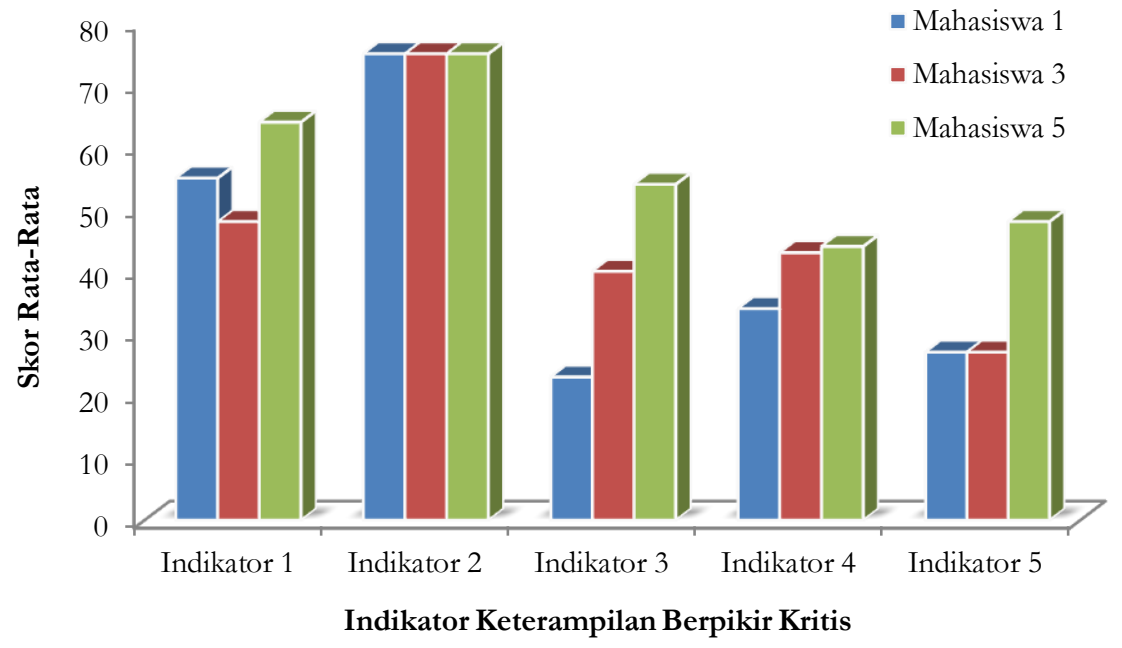

Gambar 2. Grafik tingkat keterampilan berpikir kritis setiap indikator berdasarkan hasil tes 
Berdasarkan gambar di atas terlihat bahwa pada indikator kedua baik mahasiswa semester 1, 3 maupun 5 semuanya berada pada kriteria keterampilan berpikir kritis tingkat tinggi yaitu dengan skor rata-rata 75. Ini berarti mahasiswa pendidikan kimia memiliki kemampuan membangun keterampilan dasar pada level tinggi. Pada indikator pertama, memberikan penjelasan sederhana secara skor rata-rata tes keterampilan mahasiswa pada indikator ini berada pada kriteria cukup. Jika dilihat per angkatan semester, mahasiswa semester 5 memiliki keterampilan memberikan penjelasan sederhana pada kriteria tinggi. Kemampuan semester 5 pada indikator ini lebih baik dibandingkan mahasiswa semester 1 dan 3 yang pada indikator ini memiliki keterampilan pada kriteria cukup. Pada indikator 3, yaitu membuat kesimpulan keterampilan mahasiswa semester 5 lebih tinggi yaitu 54 pada kriteria cukup dibandingkan mahasiswa semester 3 dan 1. Artinya kemampuan membuat kesimpulan berdasarkan fakta mahasiswa semester 5 lebih baik dibandingkan mahasiswa semester 3 dan 1 .

Pada indikator keterampilan bepikir kritis keempat, yaitu memberikan penjelasan lanjut, kemampuan mahasiswa semester 5 lebih baik dibandingkan mahasiswa semester 3 dan 1 . Meskipun untuk indikator ini berdasarkan skor rata-rata mahasiswa pendidikan kimia memiliki kemampuan yang rendah untuk memberikan penjelasan lanjut tentang sebuah konsep. Pada indikator keterampilan berpikir kritis kelima yaitu menyusun strategi dan taktik, secara rata-rata skor mahasiswa pendidikan kimia memiliki kemampuan yang rendah dalam menyusun strategi dan taktik untuk menyelesaikan sebuah permasalahan. Mahasiswa semester 5 memiliki kemampuan yang lebih baik dalam menyusun strategi dan taktik yaitu pada kriteria cukup dibandingkan mahasiswa semester 1 dan 3 yang kemampuannya berada pada kriteria rendah.

\section{Hasil Pencapaian Keterampilan Berpikir Kritis Berdasarkan Kuisioner}

Hasil pengolahan dan analisis data kuisioner keterampilan berpikir kritis yang dilakukan terhadap 30 orang mahasiswa didapatkan tabel berikut ini:

Tabel 4. Distribusi frekuensi hasil kuisioner keterampilan berpikir kritis mahasiswa

\begin{tabular}{cccc}
\hline No. & Rentang Perolehan Skor & frekuensi & Kriteria \\
\hline 1 & $0-19$ & 0 & Sangat rendah \\
\hline 2 & $20-39$ & 0 & Rendah \\
\hline 3 & $40-59$ & 20 & Cukup \\
\hline 4 & $60-79$ & 10 & Tinggi \\
\hline 5 & $80-100$ & 0 & Sangat tinggi \\
\hline & Rata-rata & $\mathbf{5 8}$ & Cukup \\
\hline
\end{tabular}

Sesuai dengan tabel 4 di atas dapat disimpulkan bahwa berdasarkan skor rata-rata kuisioner, mahasiswa calon guru kimia memiliki tingkat kemampuan berpikir kritis yang cukup dengan rata-rata skor 58. Berdasarkan kuisioner yang diberikan, tidak ditemukan mahasiswa yang memiliki kemampuan berpikir kritis sangat rendah, rendah dan sangat tinggi. Mahasiswa yang berada pada kriteria cukup berjumlah 20 orang. Mahasiswa yang memiliki keterampilan berpikir kritis tinggi berjumlah 10 orang dan tidak terdapat mahasiswa yang berhasil meraih skor diatas 80 artinya tidak ada mahasiswa yang memiliki keterampilan berpikir kritis pada kriteria sangat tinggi.

Hasil pengolahan data kuisioner keterampilan berpikir kritis ini selanjutnya dianalisis lebih lanjut berdasarkan tingkat atau semester perkuliahannya. Berdasarkan hasil analisis skor tes masing-masing tingkatan semester didapatkan data sbb:

Tabel 5. Kriteria keterampilan berpikir kritis mahasiswa berdasarkan semester

\begin{tabular}{cccc}
\hline No. & Semester & Skor rata-rata & Kriteria \\
\hline 1 & 1 & 55 & Cukup \\
\hline 2 & 3 & 57 & Cukup \\
\hline 3 & 5 & 65 & Tinggi \\
\hline
\end{tabular}


Berdasarkan tabel 5 di atas terlihat bahwa mahasiswa pendidikan kimia semester 1 dan 3 memiliki skor kemampuan berpikir kritis yang berada pada kriteria cukup. Sementara itu, mahasiswa semester 5 memiliki kemampuan berpikir kritis pada kriteria tinggi. Meskipun terdapat perbedaan skor rata-rata kuisioner. Data kuisioner ini juga menunjukkan perbedaan tingkat kemampuan berpikir kritis per tingkatan semester mahasiswa. Secara ringkas hasil pengelompokkan skor berdasarkan tingkatan semesternya dijabarkan dalam grafik berikut ini.

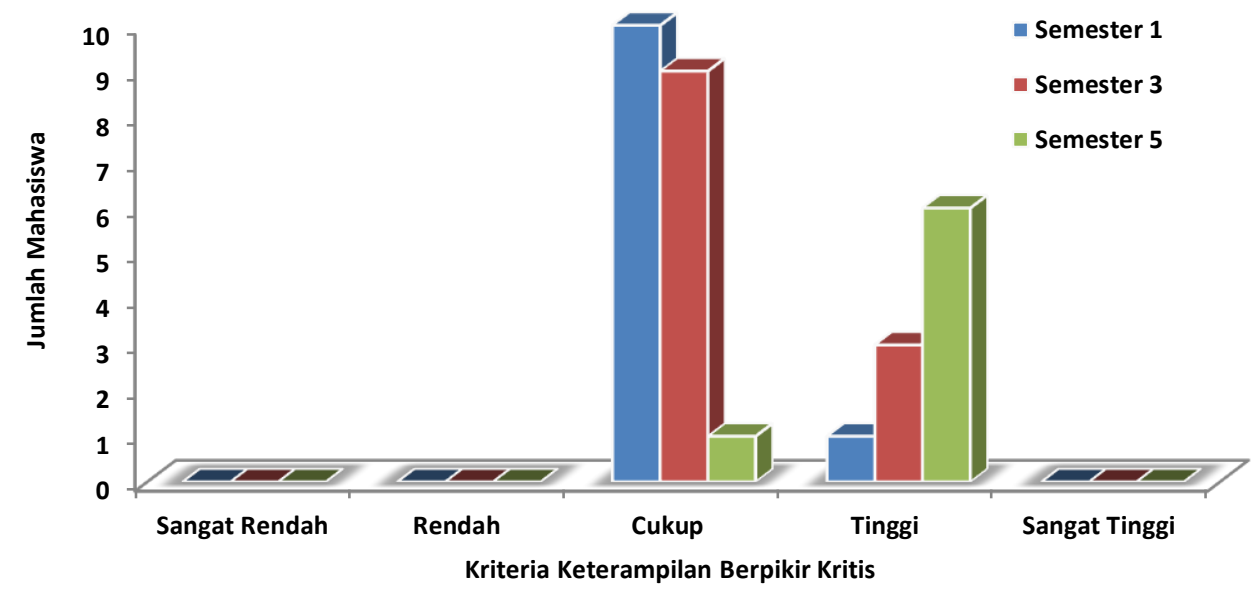

Gambar 3. Grafik tingkat keterampilan berpikir kritis mahasiswa berdasarkan kuisioner

Berdasarkan grafik di atas, terlihat bahwa baik mahasiswa semester 1,3 maupun 5 tidak ada yang memiliki skor tes pada kriteria kemampuan berpikir kritis sangat tinggi, sangat rendah dan rendah. Sementara itu jumlah mahasiswa semester 1 yang berada pada kiteria cukup lebih banyak dibandingkan mahasiswa semester 3 dan 5 yaitu masing-masing 10 orang, 9 orang dan 1 orang. Pada kriteria keterampilan berpikir kritis tingkat tinggi jumlah mahasiswa semester 5 yang berhasil memperoleh skor pada kriteria ini lebih banyak dibandingkan mahasiswa semester 3 dan 1 yaitu masing-masing 6 orang, 3 orang dan 1 orang. Data skor kuisioner keterampilan berpikir kritis ini juga dianalisis per indikator keterampilan berpikir kritis. Hal ini dilakukan untuk memperoleh gambaran keterampilan berpikir kritis baik mahasiswa semester 1, 3 maupun 5 untuk setiap indikator kemampuan berpikir kritis. Berikut ini merupakan hasil analis skor kuisioner per indikator.

Tabel 6. Hasil kuisioner keterampilan berpikir kritis mahasiswa setiap indikator

\begin{tabular}{|c|c|c|c|c|c|c|}
\hline \multirow{2}{*}{ No } & \multirow{2}{*}{ Indikator Keterampilan Berpikir Kritis } & \multicolumn{4}{|c|}{ Rata-rata skor semester ke } & \multirow{2}{*}{ Kriteria } \\
\hline & & 1 & 2 & 3 & Rata-rata & \\
\hline 1 & $\begin{array}{l}\text { Memberikan penjelasan } \\
\text { (memfokuskan pertanyaan, menganalisis } \\
\text { argumen dan memberikan penjelasan } \\
\text { sederhana }\end{array}$ & 33 & 41 & 49 & 41 & Cukup \\
\hline 2 & $\begin{array}{l}\text { Membangun keterampilan dasar } \\
\text { (mempertimbangkan kredibilitas sumber } \\
\text { dan kemampuan memberikan alasan) }\end{array}$ & 54 & 56 & 52 & 54 & Cukup \\
\hline 3 & Membuat kesimpulan berdasarkan fakta & 45 & 42 & 56 & 47,6 & Cukup \\
\hline 4 & $\begin{array}{lrr}\text { Memberikan } & \text { penjelasan } & \text { lanjut } \\
\text { (mendefinisikan istilah } & \text { dan } \\
\text { mempertimbangkannya } & \text { serta } \\
\text { menyampaikan pendapat) } & \\
\end{array}$ & 44 & 46 & 46 & 45,3 & Cukup \\
\hline 5 & $\begin{array}{lrrr}\text { Menyusun strategi } & \text { dan } & \text { taktik } \\
\text { (memutuskan suatu } & \text { tindakan } & \text { dan } \\
\text { memberikan alternatif } & & \end{array}$ & 47 & 49 & 56 & 50,7 & Cukup \\
\hline
\end{tabular}


Tabel 6 di atas merupakan data hasil analisis skor kuisioner per indikator keterampilan berpikir kritis. Berdasarkan data diatas terlihat bahwa bahwa secara rata-rata baik mahasiswa semester 1,3 maupun 5 keterampilan berpikir kritisnya untuk masing-masing indikator keterampilan berpikir kritis sama-sama berada pada kriteria cukup. Meskipun terdapat perbedaan skor rata-rata kuisioner per indikator. Data ini ini selanjutnya dianalisis, untuk melihat perbedaan skor kuisioner per indikator untuk masing-masing angkatan mahasiswa. Secara singkat, rincian skor rata-rata kuisioner keterampilan berpikir kritis per indikator keterampilan berpikir kritis untuk masing-masing tingkatan semester baik semester 1, 3 maupun 5 digambarkan pada grafik di bawah ini.

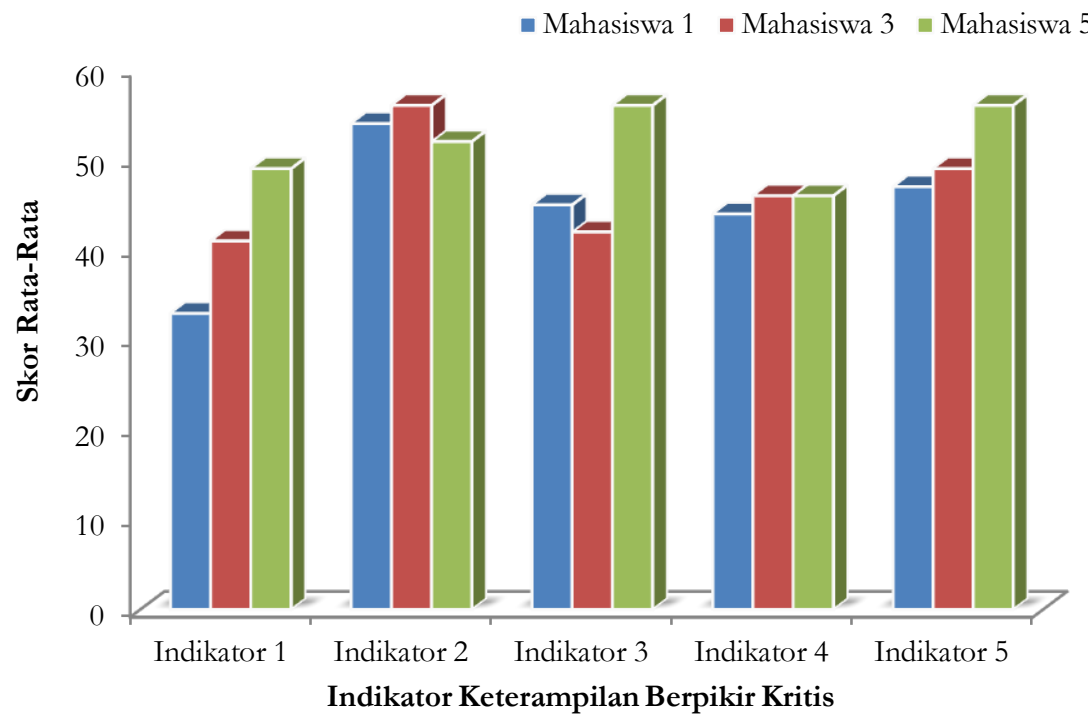

Gambar 5. Grafik tingkat keterampilan berpikir kritis mahasiswa setiap indikator berdasarkan kuisioner

Berdasarkan gambar di atas terlihat bahwa pada indikator pertama baik mahasiswa semester 3 dan 5 berada pada kriteria keterampilan berpikir kritis cukup. Sedangkan mahasiswa semester 1 berada pada kriteria rendah. Ini berarti mahasiswa pendidikan kimia semester 5 memiliki kemampuan memberikan penjelasan sederhana lebih baik dibandingkan dengan mahasiswa semester 3 dan 1. Pada indikator kedua, membangun keterampilan dasar, secara skor rata-rata kuisioner keterampilan mahasiswa pada indikator ini berada pada kriteria cukup. Jika dilihat dari tingkatan semester, mahasiswa semester 3 memiliki keterampilan memberikan penjelasan sederhana lebih baik dibandingkan mahasiswa semester 5 dan 1 . Pada indikator 3, yaitu membuat kesimpulan keterampilan mahasiswa semester 5 lebih dibandingkan mahasiswa semester 1 dan 3. Artinya kemampuan membuat kesimpulan berdasarkan fakta mahasiswa semester 5 lebih baik dibandingkan mahasiswa semester 1 dan 3 .

Pada indikator keterampilan bepikir kritis keempat, yaitu memberikan penjelasan lanjut, kemampuan mahasiswa semester 5 dan 3 lebih baik dibandingkan mahasiswa semester 1 . Artinya kemampuan memberikan penjelasan lanjut mahasiswa semester 5 dan 3 lebih baik dibanding mahasiswa semester 1. Pada indikator keterampilan berpikir kritis kelima yaitu menyusun strategi dan taktik, secara rata-rata skor mahasiswa pendidikan kimia memiliki kemampuan yang cukup dalam menyusun strategi dan taktik untuk menyelesaikan sebuah permasalahan. Mahasiswa semester 5 memiliki kemampuan yang lebih baik dalam menyusun strategi dan taktik dibandingkan mahasiswa semester 1 dan 3 .

Hadirnya era revolusi industri 4.0 menuntut semua pihak termasuk dari dunia pendidikan untuk ikut mengalami perubahan-perubahan yang signifikan sebagai upaya untuk siap bertahan dan bersaing. Hal ini kemudian mendorong lahirnya pendidikan abad 21 yang dikenal dengan 
istilah Pendidikan 4.0. Sesuai dengan kerangka pembelajaran abad 21 peserta didik dituntut untuk memiliki keterampilan 4C (Creativity, Critical Thinking, Communication and Collaboration) ((P21)., 2018).

Berdasarkan analisis dan pengolahan data hasil tes dan kuisioner keterampilan berpikir kritis menunjukkan bahwa keterampilan berpikir kritis mahasiswa pendidikan kimia masih berada pada kriteria cukup. Hasil ini perlu ditingkatkan ke kriteria yang lebih tinggi lagi, sebab keterampilan berpikir kritis merupakan salah satu bentuk keterampilan yang dibutuhkan oleh sumber daya manusia untuk menghadapi era industri 4.0. Untuk itu perlu segera dilakukan perbaikan agar mahasiswa pendidikan kimia yang merupakan calon guru dapat meningkatkan keterampilan berpikir kritisnya. Untuk memperbaiki dan meningkatkan kualitas. Perbaikan dan peningkatan kualitas pembelajaran itu dapat dilakukan dengan cara memperbaiki kurikulum, pembelajaran, bahan ajar, media pembelajaran, metode dan strategi pembelajaran, evaluasi dan peningkatan kualitas tenaga pengajarnya (Arliani \& Hidayati, 2013; Oktariani \& Febliza, 2019).

Masih rendahnya kualitas keterampilan berpikir kritis calon guru kimia ini menunjukkan masih rendahnya kemampuan kognitif mahasiswa pendidikan dalam mengolah dan mentranformasi informasi untuk mengambil suatu keputusan dan alasan berdasarkan fakta dan penalarannya (Spector \& Ma, 2019). Hal ini ditandai dengan rendahnya skor tes dan kuisioner yang diraih oleh mahasiswa. Salah satu penyebab rendahnya capaian skor mahasiswa pendidikan kimia dalam tes ini adalah tidak terbiasanya mahasiswa melakukan aktivitas ataupun menggunakan pola keterampilan berpikir kritis dalam pembelajaran (Ningsih et.al., 2018; Agustin et al., 2017).

Faktor lain penyebab rendahnya capaian keterampilan berpikir kritis calon guru kimia adalah jarangnya subjek melakukan kebiasaan yang mendorong subjek untuk memiliki keterampilan berpiki kritis sebab alat evaluasi atau ujian yang diberikan juga tidak membutuhkan keterampilan tersebut untuk menjawabnya (Hasmarani, 2019). Hal ini sejalan dengan yang dikemukakan oleh desti ritdamaya yang menyatakan bahwa rendahnya keterampilan berpikir kritis ini disebabkan oleh siswa belum terbiasa, terlatih dan terampil untuk menerapkan keterampilan berpikir kritis melalui proses pembelajaran maupun assesmennya (Ritdamaya \& Suhandi, 2015). Ini didukung juga oleh hasil penelitian yang berdasarkan kuisioner terlihat bahwa aktivitas pembelajaran yang mendorong mahasiswa untuk mengembangkan kemampuan berpikir kritisnya juga tergolong pada kriteria cukup.

Rendahnya keterampilan berpikir kritis yang dimiliki mahasiswa berdasarkan tes dan kuisioner ini juga ditandainya dengan rendahnya tingkat keterampilan berpikir kritis mahasiswa per indikator. Pada indikator keterampilan berpikir kritis pertama, memberikan penjelasan sederhana, berdasarkan tes mahasiswa pendidikan kimia berada pada kriteria cukup. Hal ini didukung juga dengan skor kuisioner yang menunjukkan bahwa aktivitas mahasiswa yang menunjukkan keterampilan berpikir kritis masih tergolong cukup. Terlihat dalam pembelajaran memang hanya sebagian mahasiswa yang mampu bertanya untuk meminta penjelasan atau memberikan jawaban dalam pembelajaran. Pertanyaan yang meminta penjelasan ini jika tidak dipikirkan dengan baik akan menyebabkan timbulnya jawaban yang tidak sesuai dengan diharapkan siswa. Jadi, siswa perlu mengidentifikasi terlebih dahulu permasalahan yang atau topik pembelajaran sehingga akan muncul pertanyaan (Fujika et al., 2015). Jadi, ketidakmampuan mahasiswa dalam merumuskan pertanyaan yang berhubungan dengan kondisi yang diberikan menyebabkan siswa sulit untuk menjawab sebuah pertanyaan tersebut secara sederhana dan tanpa penjelasan lanjut (Hollis, 2019).

Pada indikator kedua, membangun keterampilan dasar, indikator ini ditandai dengan kemampuan mahasiswa dalam menyesuaikan dan mempertimbangkan kredibilitas sumber. Hasil tes menunjukkan bahwa pada indikator ini mahasiswa memiliki capaian yang lebih baik dibandingkan dengan indikator berpikir kritis lainnya. Hasil ini juga didukung oleh data kuisioner yang menunjukkan bahwa mahasiswa ketika menyampaikan argumen dan pendapat serta jawaban pertanyaan akan bersumber pada sumber yang kredibel dan tepat serta menggunakan alasan yang tepat untuk menyanggah sesuatu. Kemampuan mahasiswa membangun keterampilan dasar ini 
merupakan salah satu kemampuan yang harus dikembangkan untuk meningktakan keterampilan berpikir kritis mahasiswa (Agnafia, 2019).

Indikator keterampilan berpikir kritis yang ketiga yaitu membuat kesimpulan berdasarkan fakta. Hasil tes menunjukkan bahwa pada indikator ini kemampuan mahasiswa pendidikan masih berada pada kriteria rendah. Hal ini didukung dengan data kuisioner yang menunjukkan bahwa reandahnya aktivitas siswa yang mendorong siswa untuk mengembangkan kemampuannya untuk membuat sebuah kesimpulan atau mempertimbangkan hasil induksinya. Untuk itu dalam pembelajaran dosen dituntut untuk membiasakan mahasiswanya untuk menyimpulkan sebuah informasi atau menguraikan berbagai aspek secara bertahap agar menghasilkan sebuah informasi atau formulasi sebagai sebuah kesimpulan (Hadzhikoleva et al., 2019).

Indikator keterampilan berpikir kritis keempat, memberikan penjelasan lanjut, kemampuan mahasiswa pendidikan kimia juga berada pada kriteria cukup. Ini artinya kemampuan mahasiswa dalam mendefinisikan istilah dan mempertimbangkannya perlu ditingkatkan lagi. Seorang pemikir kritis perlu benar-benar memahami sebuah ide dan menyadari perlunya informasi baru untuk dipertimbangkan dan dipelajari sehingga dapat mendefinisikannya (Paul \& Elder, 2007).

Indikator keterampilan berpikir kritis kelima, menyusun strategi dan taktik, berdasarkan tes menunjukan bahwa keterampilan mahasiswa pada indikator ini secara rata-rata berada pada level rendah. Meskipun berdasarkan hasil skor kuisioner mahasiswa pendidikan kimia berada pada kriteria cukup. Rendahnya keterampilan mahasiswa pada indikator ini ketika mengerjakan soal tes disebabkan oleh kurangnya kemampuan mahasiswa untuk mengambil sebuah tindakan dengan cara mengambil sendiri keputusan, menggunakan logikanya untuk mengatasi masalah, ataupun mencari solusi alternatif dan berkerja sama dengan orang lain.

Meskipun secara rata-rata mahasiswa pendidikan kimia memiliki ketrampilan berpikir kritis pada level cukup. Namun, terdapat perbedaan capaian ketermapilan berpikir kritis antara mahasiswa pendidikan kimia semester 5 dengan semester 3 dan 1 . Hal ini ditandai dengan perbedaan skor rata-rata tes dan kuisionernya. Mahasiswa semester 3 memiliki keterampilan berpikir kritis yang lebih baik dibandingkan dengan semester 1. Hal ini juga menunjukkan bahwa pengalaman dan tuntutan pembelajaran juga mempengaruhi keterampilan berpikir kritis mahasiswa. Ini sejalan dengan penelitian Ibrahim yang menunjukkan bahwa ketika ingin mengukur keterampilan seseorang maka akan lebih baik hasilnya jika orang tersebut dilatih dulu kemampuannya dalam proses pembelajaran (Rasmawan, 2017). Berdasarkan tanya jawab dengan mahasiswa semester 1 tentang metode pembelajaran yang digunakan selama SMA khususnya pada pembelajaran kimia, sebagian besar pembelajaran dilakukan dengan metode ceramah. Hal ini tentu menyebabkan siswa lebih mengutamakan cara belajar mengingat dibandingkan dengan belajara berpikir. Hal ini sejalan dengan hasil penelitian lainnya yang menunjukkan bahwa metode pembelajaran yang digunakan akan mempengaruhi keterampilan berpikir kritis peserta didik (Nur et al., 2019; Nurhayati et al., 2016; Agustin et al., 2017).

Oleh karena itu, perlu dilakukan berbagai upaya yang melibatkan semua pihak agar dapat meningkatkan keterampilan berpikir kritis calon guru kimia. Sebab calon guru kimia ini nantinya akan menjadi pendidik yang harus mengembangkan keterampilan berpikir kritis peserta didik. Tidak mungkin peserta didik dapat memiliki keterampilan berpikir kritis jika gurunya saja masih memiliki keterampilan berpikir kritis yang rendah. Adapun beberapa hal yang dapat dilakukan untuk meningkatkan keterampilan berpikir kritis mahasiswa calon guru kimia ini diantaranya adalah dengan mengembangkan keterampilan berpikir kritis mahasiswa melalui pembelajaran karena keterampilan berpikir tidak otomatis dimiliki mahasiswa melainkan melalui pembelajaran.

Keterampilan berpikir kritis dalam pembelajaran dapat dikembangkan dengan menggunakan berbagai metode pembelajaran yang berpusat pada siswa atau (Student Centered). Adapun metode-metode yang bisa mengembangkan kemampuan berpikir kritis dalam pembelajaran sains diantaranya: Problem Based Learning, Project Based Learning, Pembelajaran 5L, 
Learning Cycle 7E (Chairani \& Muchlis, 2019; Deechai \& Sovajassatakul, 2019; Nur et al., 2019; Nurhayati et al., 2016; Agustin et al., 2017; Permana, 2018).

Selain merancang metode yang dapat meningkatkan keterampilan berpikir kritis, perlu juga dirancang alat evaluasi dan assesmen yang bertujuan untuk meningkatkan keterampilan berpikir kritis mahasiswa. Sebab, adanya evaluasi akan menuntut mahasiswa untuk menunjukkan kinerja yang maksimal sebagai bentuk pencapaian prestasi belajarnya. Sehingga, jika tes yang diberikan menuntut siswa untuk mengembangkan keterampilan berpikir kritisnya, maka mahasiswa akan berusaha untuk melatih keterampilan berpikir kritisnya. Evaluasi atau asesmen keterampilan berpikir kritis terdiri dari berbagai bentuk yang disesuaiakan dengan kebutuhan diantaranya, soal tes keterampilan berpikir kritis yang terintegrasi dengan pembelajaran, peer assesment dalam bentuk angket, kusisoner, daftar cek, dan sebagainya, atau bisa dalam bentuk observasi, wawancara maupun tes tulisan (Hadzhikoleva et al., 2019; Harti \& Agoestanto, 2019; Prasasti et al., 2012). Selain itu, perlu adanya peningkatan peran guru sebagai pengajar maupun dosen dalam pengembangan keterampilan berpikir kritis peserta didik dengan cara tidak lagi menggunakan metode belajar berpusat pada guru (teacher-centered).

Dalam pembelajaran guru dan dosen sebaiknya berperan sebagai pendorong, fasilitator, motivator dan pendamping. Guru harus memberikan kesempatan kepada peserta didiknya untuk mengembangkan diri. Untuk itu guru dan dosen juga perlu menyusun secara sistematis materi dan kurikulum sehingga melatih siswa menegmbangkan keterampilan berpikir kritisnya. Serta guru dan dosen dituntut untuk selalu bisa mengembangkan profesionalisme dan kompetensinya sesuai dengan bidang keahliannya. Sehingga dapat merencanakan, melaksanakan dan melakukan evaluasi yang bermanfaat bagi perkembangan kualitas pembelajaran. Memberikan perhatian lebih terhadap keterampilan-keterampilan yang perlu dikembangkan oleh mahasiswa, tidak hanya keterampilan berpikir kritis namun juga keterampilan berkolaborasi, komunikasi dan kreativitas yang dikenal dengan 4C harus terus dilakukan. Keempat keterampilan ini perlu diasah dan dikembangkan oleh mahasiswa khususnya calon guru sebagai bentuk kesiapannya menghadapi era revolusi industri 4.0. Dengan demikian mahasiswa siswa siap untuk bersaing dan menghadapi revolusi industri 4.0.

\section{SIMPULAN}

Berdasarkan hasil penelitian, maka dapat disimpulkan bahwa keterampilan berpikir kritis mahasiswa calon guru kimia masih berada pada kriteria cukup. Selain itu juga ditemukan bahwa keterampilan berpikir kritis mahasiswa semester 5 lebih baik dibandingkan semester 3 dan 1 . Hasil ini juga didukung dengan adanya perbedaan performa mahasiswa untuk masing-masing indikator keterampilan berpikir kritis. Mahasiswa pendidikan kimia menunjukkan performa yang lebih baik pada indikator membangun keterampilan dasar dibandingkan dengan indikator keterampilan berpikir kritis lainnya. Sementara itu pada indikator membangun strategi dan taktik mahasiswa pendidikan kimia masih menunjukkan performa yang kurang baik dibandingkan dengan indikator yang lainnya. Hal ini perlu segera diperbaiki guna mempersiapkan calon guru kimia yang siap bersaing menghadapi era revolusi industri 4.0. selain itu, penelitian ini juga perlu dikembangkan lagi untuk ranah keterampilan abad 21 lainnya.

\section{REFERENSI}

Agnafia, D. N. (2019). Analisis Kemampuan Berpikir Kritis Siswa Dalam Pembelajaran Biologi. Florea, 6(1), 45-53.

Agustin, Y., Fadiawati, N., \& Tania, L. (2017). Peningkatan Keterampilan Berpikir Kritis Siswa Pada Materi Laju Reaksi Melalui Pendekatan Saintifik. Jurnal Pendidikan Dan Pembelajaran Kimia, 5(3), 98-112. 
Arikunto, S. (2012). Dasar-Dasar Evaluasi Pendidikan. Jakarta: Bumi Aksara.

Arikunto, S. (2006). Prosedur Penelitian Suatu Pendekatan Praktik Edisi Revisi VI. Jakarta: PT Bina Aksara.

Arliani, E \& Hidayati, K. (2013). Model-Model Alignment Antara Penilaian dan Kurikulum Dalam Pembelajaran Matematika. Prosiding Seminar Nasional Matematika Dan Pendidikan Matematika Universitas Negeri Yogyakarta.

Chairani, R. P. \& Muchlis. (2019). Penerapan Model Pembeljaran Berbasis Masalah Untuk Melatihkan Kemampuan Berpikir Kritis Peserta Didik Pada Materi Larutan Penyangga Kelas XI di MAN 1 Sidoarjo. Unesa Journal of Chemical Education, 8(1), 16-21.

Deechai, W., \& Sovajassatakul, T. (2019). Efficiency and effectiveness of blended learning for critical thinking development in thai vocational students. Revista Espacios, 40(19).

Firman, H. (2018). Mewujudkan Pendidikan Kimia di Era Industri 4.0: Pembelajaran Berbasis STEM Sebagai Alternatif. Keynote. Seminar Nasional Pendidikan Kimia Dalam Tantangan Revolusi Industri 4.0. Jakarta.

Fujika, A., Anggereini, E., \& Budiarti, R. S. (2015). Analisis Kemampuan Berpikir Kritis Siswa Sma N 5 Kota Jambi Melalui Pembelajaran Berbasis Masalah Pada Konsep Pencemaran Lingkungan. Jurnal BIODIK, I(1), 1-10.

Greenstein, L. (2012). Assesing 21st Century Skills: A Guide to Evaluating Mastery and Authentic Learning. Corwin.: Thousand Oaks, CA.

Hadzhikoleva, S., Hadzhikolev, E., \& Kasakliev, N. (2019). Using Peer Assessment to Enhance Higher Order Thinking Skills. TEM Journal, 8(1), 242-247.

Harry, F. (2013). Metode Penelitian Kimia. Bandung.: FPMIPA UPI.

Harti, L. S., \& Agoestanto, A. (2019). Analysis of Algebraic Thinking Ability Viewed From The Mathematical Critical Thinking Ablity of Junior High School Students on Problem Based Learning. Unnes Journal Of Mathematics Education, 8(2), 119-127.

Hasmarani, S. (2019). Analisis kemampuan Peserta Didik dalam Menyelesaikan Soal Asam Basa pada Tingkat Keterampilan Berpikir Kritis dan Berpikir Kreatif di Kelas XI IPA SMA/MA di Kec. Bulukumpa. Chemistry Education Review (CER), 2(2), 93-100.

Hollis, H. (2019, June). Information Literacy and Critical Thinking: Different Concepts , Shared Conceptions. Department of Library and Information Science and Book Studies at Faculty of Arts, University of Ljubljana.

Maria, M., Shahbodin, F., \& Pee, N. C. (2018, September). Malaysian higher education system towards industry 4.0-current trends overview. In AIP Conference Proceedings (Vol. 2016, No. 1, p. 020081). AIP Publishing LLC.

Miftianah, N. N., Astuti, A. P., \& Hidayah, F. F. (2017). Analisis Keterampilan Berpikir Kritis Siswa Melalui Pembelajaran SETS Kelas X pada Materi Larutan Elektrolit dan Non Elektrolit. In Prosiding Seminar Nasional \& Internasional. 249-257

Ningsih, D. R., Ramalis, T. R., \& Purwana, U. (2018). Pengembangan Tes Keterampilan Berpikir Kritis Berdasarkan Analisis Teori Respon Butir. WaPFi (Wabana Pendidikan Fisika), 3(2), 45-50.

Nurhayati, H. M., Rahayu, S., \& Yahmin, Y. (2016). Pengaruh Pembelajaran Kimia Kelarutan dengan LC-5E Berkonteks SSI terhadap Keterampilan Berpikir Kritis Siswa SMA. Jurnal Pendidikan Sains, 4(4), 137-143.

Nur, W., Wan, T., Harun, J., \& Shukor, N. A. (2019). Problem Based Learning to Enhance Students 
Critical Thinking Skill via Online Tools. 15(1), 14-23.

Oktariani, O., \& Febliza, A. (2019). Analysis of The Alignment Between Chemistry Content on TIMSS And Science-Chemistry Textbooks of Junior High SchoolAnalysis of The Alignment Between Chemistry Content on TIMSS And Science-Chemistry Textbooks of Junior High School. JPI (Jurnal Pendidikan Indonesia), 8(1), 123-132.

(P21)., P. for 21st C. skills. (2018). Framework for 21 Century Learning. Retrieved from http://www.p21.org/our-work/p21 framework.

Paul, R., \& Elder, L. (2007). The miniatur guide to critical thinking concepts and tools. California: Foundation for Critical Thinking Press.

Permana, N. D. (2018). Penerapan Model Pembelajaran Learning Cycle 7E Berbantuan Website Untuk Meningkatkan Keterampilan Berpikir Kritis Siswa Pada Materi Kinematika Gerak Lurus. Journal of Natural Science and Integration, 1(1), 11-41.

Prasasti, Y. R., \& Suyono \& Basuki, A. I. (2012). Pengembangan Instrumen Asesmen Berpikir Kritis Melalui Membaca Untuk Siswa SD/MI. Jurnal Universitas Negeri Malang.

Rasmawan, R. (2017). Profil keterampilan berpikir kritis mahasiswa dan korelasinya dengan indeks prestasi akademik. 2(2), 130-140.

Ritdamaya, D., \& Suhandi A. (2015). Profil Keterampilan Berpikir Kritis Siswa Sekolah Menengah Atas dalam Materi Suhu dan Kalor Menggunakan Instrumen Tes Berpikir Kritis Ennis. Seminar Nasional Fisika Dan Aplikasinya, 123-130.

Rudinov, J., \& Barry, V. E. (2004). Invitation Critical Thinking. New York: Holly J. Allen.

Saputri, A. C. Sajidan, \& Rinanto, Y.(2017). Identifikasi Keterampilan Berpikir Kritis Siswa dalam Pembelajaran Biologi Menggunakan Window Shopping. In Seminar Nasional Pendidikan Sains (pp. 131-135).

Spector, J. M., \& Ma, S. (2019). Inquiry And Critical Thinking Skills for The Next Generation: From Artificial Intelligence Back to Human Intelligence. Smart Learning Environments, 6(1), $1-11$

Supriyati, E., Setyawati, O. I., Purwanti, D. Y., Salsabila, L. S., \& Prayitno, B. A. (2018). Profil Keterampilan Berpikir Kritis Siswa SMA Swasta di Sragen pada Materi Sistem Reproduksi. Bioedukasi: Jurnal Pendidikan Biologi, 11(2), 72-78.

Trilling, B., \& Fadel, C. (2009). 21st Century Skills: Learning for Life in our Times. San Francisco: California jossey-bass/ John Willey \& sons. Inc.

Wagner, T. (2017). Overcoming the Global Achievement Gap. Retrieved January 20, 2019, from https://www.cosa.k12.or.us/downloads/profdev/Seaside 2009/Tony Wagner.pdf.

Yunita, S., Rohiat, S., \& Amir, H. (2018). Analisis Kemampuan Berpikir Kritis Mata Pelajaran Kimia pada Siswa Kelas XI IPA SMAN 1 Kepahiang. Jurnal Pendidikan \& Ilmu Kimia (Alotrop), 2(2), 33-38. 